\title{
Found in Translation
}

Eka Kurniawan and the Politics of Genre

\author{
Meghan Downes \\ Monash University \\ meg.downes@monash.edu
}

\begin{abstract}
Indonesian author Eka Kurniawan achieved huge critical success globally during 20152016 with his translated novels Beauty is a wound and Man tiger, which have been praised for their sweeping historical scope, 'magical realist' elements, and experimentation with voice and genre. First published in the Indonesian language more than a decade earlier as Cantik itu luka and Lelaki harimau, these novels initially faced a relatively lukewarm reception locally. Only once Eka Kurniawan's work had been 'found in translation' was he taken more seriously in Indonesian media coverage. This article charts Eka Kurniawan's rise to literary fame, paying particular attention to the shifting tone and content of reviews, marketing, cover art, and media representations, as the translated novels circulated globally. I use this case to examine two key issues: firstly, the ways in which certain genres such as horror and crime are 'othered' in the Indonesian literary landscape; and secondly, how processes of translation, distribution, and reception outside Indonesia can significantly impact local interpretations of an author and their work. In doing so, this article demonstrates that the politics of genre and the power relations of international publishing both contribute to complex patterns of inclusion and exclusion from 'local' and 'global' literary canons.
\end{abstract}

\section{Keywords}

translation - literature - Indonesia - genre - media 
During 2015-2016, Indonesian author Eka Kurniawan's translated novels Beauty is a wound and Man tiger achieved huge critical success globally. His work attracted high praise for its sweeping historical scope, its 'magical realist' elements, and its experimentations with voice and genre. This warm reception contrasts sharply with the limited critical acclaim or attention given locally to the original, Indonesian-language versions of the novels-Cantik itu luka (2002) and Lelaki harimau (2004) — when first published more than a decade earlier. Indonesian publishers and reviewers at the time had been largely unimpressed by Eka Kurniawan's fanciful approach to history, his ambiguous genre choices, and - perhaps most significantly — the 'vulgarity' and sexually explicit nature of his language and content. However, the tone and volume of the Indonesian coverage shifted markedly following his success outside Indonesia, becoming far more frequent and positive.

This is in many ways a familiar story, as postcolonial scholars have long drawn attention to how recognition and validation from centres of global literary power and taste-making largely dictate the success of authors writing from more peripheral contexts (Casanova 2004; Spivak 1985). In the fields of world literature and translation studies, the act of translation itself is characterized variously as an act of mediation (Lefevere 1992, 2012), manipulation (Sengupta 1996), violence (Dingwaney and Maier 1996), negotiation (Bassnett 2013), or as a complex combination of all these processes, that offers 'an especially revealing entry point into the dynamic of cultural identity formation in the colonial and post-colonial contexts' (Viswanatha and Simon 2012:162).

In this article, I seek to revisit some of these issues from a different perspective: rather than focusing on the role of the translator as a mediating figure, I examine the stories and fragments that circulate around the novels as an alternative site of translation. Sometimes called 'intertexts' or 'paratexts', the reviews, interviews, and media coverage of an author and their work, as well as marketing strategies and visual elements, such as cover art, are important framing mechanisms that surround and position a novel in public discourses. ${ }^{1}$ For Eka Kurniawan, these informal sites of translation have significantly impacted his reputation in Indonesia, and therefore warrant close analysis.

1 While the terms 'intertext' and 'paratext' can originally be attributed to Fiske (1989) and Genette (1997) respectively, the various visual fragments and stories surrounding a text have since become well-established sites of analysis in media and cultural studies. 
Eka Kurniawan's rise to global literary fame raises important questions around the politics of genre in Indonesia and the power relations of international publishing. Genre is a key theme in the stories that circulate, both nationally and internationally, about Eka Kurniawan and his work. His novels display genre markers from horror, crime, and pulp fiction-all styles of writing that have long been excluded from the Indonesian literary canon - and this is arguably a crucial reason for the initially lacklustre local reception of his work. Yet, in the international literary landscape, the English translations were framed in a very different way: as 'magical realism', 'historical fiction', and 'family saga'. As I will demonstrate in this article, once viewed through the prism of these other genre labels, some of the horror and crime stigma began to dissipate within the Indonesian market.

The lens of 'global success' has been another significant interpretive frame, and this article also shows how the processes of translation, distribution, and reception outside Indonesia can significantly impact local interpretations of an author and their work. The translation process for Cantik itu luka / Beauty is a wound was set in motion by the late Benedict Anderson, a towering figure in the field of Asian Studies and long-time supporter of Eka Kurniawan. Therefore, in the specific dynamics of this case, we can see the power structures of area studies academia intersecting with the global politics of publishing and the local politics of genre in fascinating ways, making the case of Eka Kurniawan a productive entry point for examining complex patterns of inclusion and exclusion from 'local' and 'global' literary canons.

Born in 1975 in Tasikmalaya, West Java, and now living in Jakarta, Eka Kurniawan is an author of novels, short stories, non-fiction, and television drama scripts. For the purposes of this article, I focus on his two early novels, Cantik itu luka (2002), later translated by Annie Tucker as Beauty is a wound (2015a), and Lelaki harimau (2004), later translated by Labodalih Sembiring as Man tiger (2015b). Beauty is a wound is a sweeping story that loosely follows the life of Dutch-Indonesian prostitute Dewi Ayu and her four daughters through the violent history of twentieth-century Indonesia: from the Dutch colonial era, through to the Japanese occupation, the independence struggle, the anticommunist violence, and the corruption and eventual downfall of the New Order regime. Set in the fictional Javanese city of Halimunda, the non-linear narrative frequently digresses into different eras and also moves between different realities, as supernatural occurrences and mythical creatures pervade 
the characters' lives. Frequent scenes of rape, bestiality, incest, murder, and hauntings are all recounted in a darkly humorous and irreverent narrative voice throughout the hefty four-hundred-page saga.

In contrast, Man tiger is a much shorter and more contained novel, told for the most part in a far more linear and realist register. Set in a small Indonesian village, the story begins with a quiet and gentle young boy named Margio murdering his neighbour Anwar Sadat; it then traces the complex background to this unexpected event, revealing histories of family violence, and also the existence of a white-tiger spirit living inside Margio. The novel's disruptive central occurrence (the murder and its supernatural aspects) contrast sharply with Man tiger's otherwise highly naturalistic portrait of the minutiae of village life and the everyday banality of domestic violence within Margio's home.

Eka Kurniawan self-published Cantik itu luka in 2002, with the support of a grant from the Yogyakarta Cultural Academy, after the manuscript was initially rejected by four Indonesian publishers (see Kurniawan 2008). Although not widely acclaimed, the novel made sufficient impact in the Indonesian literary scene to be picked up by publishing house Gramedia and reissued in 2004, along with Eka's next novel, Lelaki harimau. Yet, even after the re-release, his work continued to receive relatively scant public attention in Indonesia. ${ }^{2}$ In 2006, Cantik itu luka was translated into Japanese as Bi wa kizu by Ribeka Ota and released in Japan. Again, the publication process in Japan was a relatively small-scale and self-initiated personal endeavour, with the translator coming across the novel while in Indonesia, and then co-publishing it with the independent publishing house Shinpusha. ${ }^{3}$

Then, in 2015, almost a decade later, English translations of both novels were released to widespread praise, and Eka's work has now been translated into more than 30 languages. Beauty is a wound was listed on eight international 'best book' lists of 2015 and Eka himself has won several awards and honours, including Foreign Policy's Global Thinkers of 2015. Man tiger won IKAPI's Book of the Year in 2015, the Financial Times/Oppenheimer Fund's Emerging Voices Fiction Award in 2016, and a nomination for the 2016 Man Booker International Prize, while Beauty is a wound was awarded the 2016 World Readers' Award. By the end of 2016, Eka Kurniawan had achieved global literary fame, including back home in Indonesia.

2 There were of course some exceptions, particularly in literary and scholarly circles. For instance, Katrin Bandel devoted an entire chapter of her 2006 essay collection Sastra, perempuan, seks (Literature, women, sex) to lamenting how underappreciated Eka Kurniawan's work was in Indonesia at the time (Bandel 2006).

3 Personal communications with Ribeka Ota, 31-5-2017 and 16-10-2018. 
To understand the ten-year delay preceding Eka Kurniawan's eventual success in Indonesia, it is useful to look back at his literary influences, and at some of the reasons why his manuscripts were initially rejected. Since his childhood, Eka Kurniawan had enjoyed reading, and regularly devoured horror and martial-arts comics, as well as pulp fiction and romances sold in secret by mobile vendors. As a teenager, his favourite authors included Enny Arrow and Fredy Siswanto, who were widely known for their lurid and pornographic content. ${ }^{4}$ Later, while studying Philosophy at Universitas Gadjah Mada (Gadjah Mada University) in Yogyakarta, he began to read English translations of global literary icons such as García Márquez, Cervantes, Borges, Gogol, Chekov, Dostoyevsky, Faulkner, Hemingway, Rushdie, and Hamsun. ${ }^{5}$ The majority of media coverage about Eka Kurniawan and his work highlights this unique combination of literary influences: local Indonesian pulp fiction and the canon of 'global' high literature. The English translations of Eka's novels have been widely lauded for offering a compelling mix of 'local colour' and 'global literary merit'. However, this combination of influences is perhaps why it was such a challenge at first to have his manuscripts published in Indonesia. In interviews, Eka often tells of how:

A major publisher included a note [with the rejection letter], saying 'the novel is too literary'. I have no idea whether that's a compliment or something else. ${ }^{6}$

The editor explained their reason for rejecting Cantik itu Luka: it was lacking in literary merit. The editor said that Cantik itu Luka did not fulfil the criteria for good quality literature [...] [which should be more like] the novels of Mangunwijaya, Kuntowijoyo, and Ahmad Tohari. ${ }^{7}$

4 For more information on these books, popularly known as buku stensilan, see Smith-Hefner 2009:225. For instance, Enny Arrow was most likely not just one person but several different authors writing under a pseudonym, which took a range of different forms including Ani Arrow, Enny Ero, Eni Ero, and so on.

5 Nandini Nair, 'Eka Kurniawan: A terrible beauty is born', Open Magazine, 22-4-2016. http:// www.openthemagazine.com/article/voices/eka-kurniawan-a-terrible-beauty-is-born (accessed 16-4-2017).

6 Cited in Yuliasri Perdani, 'Eka Kurniawan: Pramoedya's successor and antithesis', The Jakarta Post, 7-9-2015. http://www.thejakartapost.com/news/2015/og/o7/eka-kurniawan-pramoedya -s-successor-antithesis.html (accessed 25-4-2017).

7 Cited in Ibad Durohman (2016b), 'Di balik mendunianya Eka Kurniawan', detikX, 9-5-2016. https:/x.detik.com/detail/metropop/201605o9/Di-Balik-Mendunianya-Eka-Kurniawan/ index.php (accessed 25-4-2017). All translations from Indonesian-language interviews are my own. For readers unfamiliar with the Indonesian literary canon, the authors mentioned in 
When my first novel (Cantik itu Luka) came out, a well-known critic gave bad review in the newspaper. He said that my novel had no direction-it is not realist nor was it surrealist. ${ }^{8}$

The sense that Eka Kurniawan's work is simultaneously too literary, but also not literary enough, neither realist nor surrealist, suggests a discomfort among publishers over the disruption of genre conventions. Eka explains that in Indonesia, many critics and reviewers see Cantik itu luka as 'a failed literary piece because of its [lack of] accuracy in history and genre' (Ramakrishnan 2016). In other words, genre fluidity and a blurring of the boundaries between high and low culture-one of the characteristics of Eka Kurniawan's work that gained him so much admiration in the English-language press and literary establishment—is precisely what unsettled so many publishers and reviewers in Indonesia.

Another central concern among Indonesian readers and reviewers of Eka Kurniawan's work was the 'vulgar' nature of scenes and language in the novels. ${ }^{9}$ His work has been described as 'a dirty book wrapped up as literature' (buku mesum yang bersembunyi dalam balutan sastra)..$^{10}$ According to Eka, in contrast to the English-language reception of his novels, Indonesian readers are 'far more critical':

this passage-Mangunwijaya, Kuntowijoyo, and Ahmad Tohari-are well-respected Indonesian authors who were active primarily during the 1980s-199os. Yusuf Bilyarta Mangunwijaya (1929-1999), popularly known as Romo Mangun, was a writer, architect, and Catholic priest whose fiction and non-fiction, including Burung-burung manyar (The weaverbirds, 1981) and Durga/Umayi (1991), examined themes of national identity and social justice. Kuntowijoyo's (1943-2005) prose, poetry, and short stories were often highly introspective, and explored various aspects of his Islamic and Javanese identity. Ahmad Tohari (born 1948) is most famous for his trilogy Ronggeng dukuh Paruk (The dancer of Paruk village, 1981), set in a small, Central Javanese village during the anti-communist mass killings of 1965-1966. For more detail on each of these authors, see Rahmanto 2001, Anwar 2007, and Cooper 2004 respectively. Notably, while Kurniawan's books share themes, settings, and backgrounds with the work of these canonical authors, his more 'lurid' pulp fiction literary aesthetic appears to have set him firmly apart from them.

8 Cited in S. Bissme, 'Author's literal take on Indonesia', The Sun Daily, 23-7-2014. http://www .thesundaily.my/news/1122284 (accessed 16-4-2017).

9 S. Bissme, 'Author's literal take on Indonesia', The Sun Daily, 23-7-2014. http://www.thesund aily.my/news/1122284 (accessed 16-4-2017).

10 Muhammad Hilmi, 'Tulisan dan sastra bersama Eka Kurniawan', Whiteboard Journal, 107-2015. http://www.whiteboardjournal.com/interview/2485o/tulisan-dan-sastra-bersama -eka-kurniawan/ (accessed 25-4-2017). 
There have been a few sections that Indonesians found to be too vulgar. Even though the translation is very faithful to the original text, maybe those scenes don't sound as vulgar in English as they do in Indonesian. ${ }^{11}$

From my own reading of the two versions, the language indeed comes across as somewhat more crude and suggestive in Indonesian than it does in English, and this is an opinion I have encountered in many conversations with other readers who have read the novels in both Indonesian and English. Because of this, the two versions of Eka Kurniawan's work take on quite different connotations, and almost appear to shift in genre during the translation process. The style of vocabulary used in the Indonesian-language version is frequently lurid, graphic, and lower class, which upon first reading can situate his work firmly in the genre of pornography, horror, and pulp fiction. Meanwhile, in English, the language comes across as edgy and creative, full of 'local colour' and so-called 'magical realism'.

This phenomenon resonates with the classic work of translation scholars such as Andre Lefevere (1992, 2012), who see translation as a process of 'refraction' in which the translator decodes and re-encodes the texts according to complex 'cultural grids' that determine how reality is constructed in the source and target language (see also Bassnett 2013). These cultural grids include the connotations of different vocabulary choices, as well as specific histories of, and interplays between, morality and genre in different social contexts. The case of Eka Kurniawan exemplifies the kinds of refractions that can occur in translation, refractions caused by both substantive differences in language and also by contextual politics of genre and taste, as I will demonstrate in the next two sections.

\section{Lost and Found in Translation}

After many years languishing in Indonesian bookstores, the fate of Eka Kurniawan's novels changed when he attracted a powerful champion: the late Benedict Anderson. As early as 2008, Anderson had extolled Eka Kurniawan's overlooked virtues, explaining that although some of Eka's readers 'find many of his

11 Cited in Tim Mann, 'Interview: Eka Kurniawan on "Beauty is a wound"', Indonesia @Melbourne, 31-8-2015. http://indonesiaatmelbourne.unimelb.edu.au/interview-eka-kurniawa n-beauty-wound/ (accessed 16-4-2017). 
writings distinctly morbid, even perverse, in their fascination with murder, violent sex, monsters, and the supernatural', what is often overlooked is 'the sheer, queer elegance of his Indonesian prose, which at its best is superior even to Pramoedya's; his black sense of humor, quite close to Pram's as well as Twain's; and his gift for parody and ear for how his fellow Indonesians (of different groups and generations) speak' (cited in Kurniawan 2008). A key supporter and patron, Anderson, along with translator Annie Tucker and other public intellectuals such as Tariq Ali, played an important role in setting in motion the English translation and us publication of Cantik itu luka as Beauty is a wound, a move that in turn was to have a significant impact on Eka Kurniawan's local reputation. Anderson, as a renowned figure in the field of Asian Studies, gave Eka access to the channels of power needed to enter the us market, and hence the 'global' market.

Shortly after the release of Beauty is a wound in English translation, Eka Kurniawan was included in the Publishers Weekly 2015 list of 'Writers to Watch', and global interest in, and acclaim for, his work grew exponentially. ${ }^{12}$ Eka was suddenly in huge demand, described in various media and literary outlets as 'burning bright'; 13 the 'crown prince' of Indonesian literature; a 'successor to Indonesia's greatest writer, Pramoedya Ananta Toer'; ${ }^{14}$ and 'Indonesia's most original living writer of novels and short stories, and its most unexpected meteorite' (Anderson 2016). While the Indonesian-language press had been concerned with vulgarity and ambiguous literary merit, English-language reviews tended to focus on different aspects, which can be summarized under four main areas. Firstly, Eka's place within the canon of so-called 'magical realism'. He gets filed - alongside authors like Garcia Marquez — into this general category, which, as I will discuss below, often functions as code for literature by a non-Western 'other'. Secondly, the influence of Hindu-Javanese oral storytelling traditions on Eka's work, which supposedly shapes his digressive narrative and large cast of colourful characters. Thirdly, his confronting exposition of Indonesia's violent history, with the town of Halimunda and Dewi Ayu's family frequently seen as a microcosm of Indonesian history. Finally,

12 Daniel Lefferts, 'A quixotic journey through Indonesian history and myth', Publishers Weekly, 10-7-2015. https://www.publishersweekly.com/pw/by-topic/authors/profiles/artic le/67465-writers-to-watch-fall-2015-eka-kurniawan.html (accessed 25-4-2017).

13 Jon Fasman, 'Burning bright', The Economist, 23-1-2016. https://www.economist.com/news /books-and-arts/21688833-brash-worldly-and-wickedly-funny-eka-kurniawan-may-be-so uth-east-asias-most-ambitious (accessed 16-4-2017).

14 Jewel Topsfield, 'Eka Kurniawan a successor to Indonesia's greatest writer, Pramoedya Ananta Toer', The Sydney Morning Herald, 22-8-2015. 
his genre experimentations, featuring a unique mix of historical fiction, family saga, horror story, and murder mystery.

The first three aspects - magical realism, local traditions, and national history-are the most commonly raised discussion points in the English-language press. For example, Jon Fasman writes in The New York Times that 'Kurniawan owes a clear debt to García Márquez, particularly in Beauty Is a Wound'.${ }^{15}$ Fasman describes how the fictional town of Halimunda functions in a similar way to García Márquez's Macondo and Faulkner's Yoknapatawpha County, allowing him to show 'how the currents of history catch, whirl, carry away and sometimes drown people'. He adds that Eka is also 'indebted' to Indonesia's oral traditions, which have contributed to stories that are 'digressive yet riveting' and characters that are 'distinct and profound', and established not so much via dialogue, but through the narrator telling us 'what the characters do and how they feel, just as a storyteller would. ${ }^{16}$ Deborah Smith's review in The Guardian, makes a similar assessment when she notes that along with 'elements familiar from magical realism' in Eka's work, 'there is also the influence of Indonesian storytelling traditions, derived from classical Indian epics such as the Ramayana, and of the Wayang puppet theatre', which 'results in digressive stories with a large cast of colourful characters.' ${ }^{17}$ In the Financial Times, Lucy Popescu echoes this idea, labelling Eka's work as 'magical realism' that has been influenced by 'Indonesia's oral storytelling tradition' and explaining how the family saga of Beauty is a wound acts as a microcosm of Indonesian history ${ }^{18}$ Popescu explains how three men-'bandit Maman Gendeng, independence fighter Shodancho, and Comrade Kliwon, a communist leader'-are all 'in thrall to Dewi Ayu and her exquisite offspring', and suggests that the fate of women in Indonesia 'was largely determined by such men', from Dutch colonizers to Japanese occupiers, independence fighters, and Suharto loyalists.

15 Jon Fasman, "Beauty is a wound" and "Man tiger" by Eka Kurniawan', The New York Times, 9-9-2015. https://www.nytimes.com/2015/o9/13/books/review/beauty-is-a-wound -and-man-tiger-by-eka-kurniawan.html (accessed 16-4-2017).

16 Jon Fasman, "Beauty is a wound" and "Man tiger" by Eka Kurniawan', The New York Times, 9-9-2015. https://www.nytimes.com/2015/o9/13/books/review/beauty-is-a-wound -and-man-tiger-by-eka-kurniawan.html (accessed 16-4-2017).

17 Deborah Smith, 'Man tiger by Eka Kurniawan review: The animal within', The Guardian, 2811-2015. https://www.theguardian.com/books/2015/nov/28/man-tiger-eka-kurniawan-rev iew-crime-novel-indonesian (accessed 16-4-2017).

18 Lucy Popescu, "Beauty is a wound" and "Man tiger" by Eka Kurniawan', Financial Times, 3o-7-2016. https://www.ft.com/content/3643ddb2-527f-11e6-9664-eobdc13c3bef (accessed 16-4-2017). 
The recurrence of terms like 'magical realism' and 'local tradition' in these reviews requires further critical analysis, as it is part of a broader tendency for literature by non-Western authors to be exoticized in the English-language literary press. As David Damrosch $(2017: 106,13)$ has warned, in the hunt for 'the next' Marquez or Rushdie, 'the new global literary market offers writers great opportunities, but it poses dangers as well' and we should 'beware the perils of exoticism and assimilation, the two extremes on the spectrum of difference and similarity'. There is a stark contrast between the initial Indonesian reviews, which characterize Eka Kurniawan's work as pornographic and trashy, and the reviews of Eka's translated work, which characterize the novels as exotic and whimsical. A passage from Louise Doughty of The Guardian is illustrative:

Kurniawan grew up in an isolated coastal village in West Java in a house with no books, but after evening prayers at the local mosque, the village children would gather on the porch of an elderly woman who would tell them magical tales. ${ }^{19}$

This romantic scene featuring local oral traditions is far removed from the image of the young Eka clandestinely buying pornographic pulp fiction from travelling vendors, and then swapping it amongst his friends. Evidently, while some of the grittier elements of Eka's work, and indeed his life story, have been lost in translation, other elements have been added. Here, transnational media coverage and reviews function as important framing mechanisms, positioning how the novels are interpreted, particularly with regard to genre.

\section{$4 \quad$ Politics of Genre and Taste in Indonesia}

Both Cantik itu luka and Lelaki harimau display distinctive characteristics of the horror and crime genres. The English-language version of Man tiger has been characterized as a 'reverse whodunnit', a 'murder mystery of sorts', 'a distinctly Javanese take on the hard-boiled genre', and 'thrilling like a good crime novel'. Nur Salleh, of The Straits Times, describes Man tiger as a crime novel in reverse, which 'reveals both murderer and murdered in the first sentence' and mixes 'murder mystery with family drama and myth.' ${ }^{20}$ According to Jon Fas-

19 Louise Doughty, “"17, ooo islands of imagination”: Discovering Indonesian literature', The Guardian, 28-5-2016. https://www.theguardian.com/books/2016/may/28/why-isnt-more -indonesia-literature-translated-english (accessed 16-4-2017).

Nur A.M. Salleh, 'Indonesia is a country that comes from blood', The Straits Times, 12-6- 
man in The Economist, it is a testament to Eka Kurniawan's storytelling gifts, 'particularly his skill at ratcheting up and tactically releasing tension, that he keeps readers enthralled', despite the unexpected early reveal of both victim and perpetrator. ${ }^{21}$ In The Guardian, Deborah Smith writes that this 'supernatural tale of murder and desire fascinatingly subverts the crime genre', and that Man tiger is particularly effective in 'deploying some of the classic techniques of the crime genre while subverting others.' ${ }^{22}$ In his detailed analysis of the novel's crime fiction elements, Eric Wilson examines several specific genre tropes, including aspects of the classic 'procedural', 'serial killer', and 'femme fatale' storylines (Wilson 2016a, 2016b). Eka Kurniawan himself explains that Man tiger deliberately sets out to play with the conventions of crime fiction, shifting the focus to 'the psychology behind murder. What makes a man kill?' According to Eka:

traditional crime fiction is always chasing after the murderer, but I wanted to reveal him first. Sometimes the motive is more important than who did it. That's where the real story is. ${ }^{23}$

In other interviews, he has described his other novel, Beauty is a wound, primarily as a horror story:

My first intention was to write a ghost story, and you can still read Beauty is a wound in that way. It's the story of a ghost's vengeance, and I had to provide the background for the ghost's revenge. That's how the novel became what it is now. I don't mind if people read the novel as a metaphor for Indonesia's troubled history, but first and foremost it's a ghost story. $^{24}$

2016. http://www.straitstimes.com/lifestyle/arts/indonesia-is-a-country-that-comes-fro m-blood (accessed 16-4-2017).

21 Jon Fasman, 'Burning bright', The Economist, 23-1-2016. https://www.economist.com/news /books-and-arts/21688833-brash-worldly-and-wickedly-funny-eka-kurniawan-may-be-so uth-east-asias-most-ambitious (accessed 16-4-2017).

22 Deborah Smith, 'Man tiger by Eka Kurniawan review: The animal within', The Guardian, 2811-2015. https://www.theguardian.com/books/2015/nov/28/man-tiger-eka-kurniawan-rev iew-crime-novel-indonesian (accessed 16-4-2017).

23 Cited in Nur A.M. Salleh, 'Indonesia is a country that comes from blood', The Straits Times, 12-6-2016. http://www.straitstimes.com/lifestyle/arts/indonesia-is-a-country-that-comes -from-blood (accessed 16-4-2017).

24 Cited in Alice Lewinsky, 'A Q\&A with Eka Kurniawan', Text Publishing, 19-8-2015. https:// www.textpublishing.com.au/blog/a-q-and-a-with-eka-kurniawan (accessed 25-4-2017). 
Eka Kurniawan's engagement with the horror genre is reflected clearly in the original cover art of both his novels, which pays obvious homage to classic horror signifiers. An early version of Cantik itu luka features a woman's head with jet-black hair cascading across her pale, naked shoulders. Her otherwise beautiful features are somewhat marred by claws protruding from her neck and jawline, crimson scratches and rivulets of blood running across her cheeks. The first print of Lelaki harimau is similarly unsettling: a man-beast hybrid screams up from the cover, long pointed fangs bared, and dark eyes scrunched up in fury. Black-and-white tiger stripes adorn his face and body, which then fades to a kind of smoky mist against the black background. As I explained in the introduction, visual fragments like these are vital framing mechanisms shaping public interpretation of a text. In the case of this early cover art, Eka Kurniawan's work is positioned firmly in the horror and pulp fiction genre.

In the Indonesian context, these genres carry particular connotations of being trashy, lower class, and morally questionable - a legacy of the 'B-grade' pulp fiction and exploitation cinema offerings of the 1970 a and 1980s. Arguably, the horror and crime elements in Eka Kurniawan's work are the reason it was initially so difficult for his novels to be accepted as serious literature in Indonesia. Crime and horror have rarely been genres deemed to have 'literary' merit - rather, they are frequently 'othered' from the notion of modern Indonesian literature and firmly excluded from national canons. The reputation of horror films at the time Eka was writing these novels would have further reinforced this exclusion, as throughout the 2ooos Indonesian horror films were, according to most viewers, synonymous with trashy, soft-core pornography (Downes 2015). For a previous research project, in which I interviewed young Indonesian film audiences, for instance, I found that middle-class audiences in particular would take great pains to explain that it was 'other', less-discerning consumers creating the demand for horror films; even if they themselves ever did watch such films, it was always in an 'ironic' way.

The connotations of different genres, and the discourses of othering that they can provoke, is an important consideration when exploring the dynamics of international translation. In the case of Eka Kurniawan, it was not until his translated work was heralded as 'magical realism', or an 'innovative blend of mythology, history, and family saga', that some of the horror and crime genre stigma began to fade within the Indonesian market. In other words, once the novels had passed through a distancing process, and become somewhat exoticized in global literary spheres, they became more acceptable in their original context, and were finally considered for inclusion as canonical national literature. 
While the reframing of genre is one important part of the puzzle, another key factor is the global power relations between 'centres' and 'peripheries' of literary production. Once seen through the prism of 'global success', the general tone of Indonesian media coverage around Eka Kurniawan and his work shifted markedly. His novels were given more time in the popular press, and many common tropes from the English-language profiles were redeployed in Indonesian. Reviews and profiles began using terms like 'historical fiction' and 'magical realism', and often placed excessive focus on Eka Kurniawan's international fame and success. In Jakarta Globe, Nico Novito introduces Eka as being 'known for his masterful blend of magical realism as well as critical take on the darker side of Indonesian history' and 'widely perceived as a leading figure who best represents the country's contemporary literary scene. ${ }^{25}$ Articles feature titles like 'Eka Kurniawan's worldwide reach' and 'Eka Kurniawan breaks through in the Netherlands', and interviewers are preoccupied by questions such as 'tell us how you have been able to break into the international market?' and 'what is the secret of your success?' Rather than engagement with the novels' content or narrative, quotes from international critics and lines such as 'the critically acclaimed novel landed him a reputation as [...]' tend to dominate reviews. ${ }^{26}$ Eka Kurniawan has joked about his sudden popularity in Indonesia, over a decade after the original publication of his novels:

According to my publisher, this year my book sales have gone up exponentially. I suppose this is a good thing. But, at the same time, it is not that great a feeling. Because honestly, my books are over a decade old. So, where were all our readers before now? ${ }^{27}$

25 Nico Novito, 'Eka Kurniawan lights up Indonesian corner of world literature scene', Jakarta Globe 17 (September 2015). http://premium.thejakartaglobe.com/features/eka-kurniawan -lights-indonesian-corner-world-literature-scene/ (accessed 25-4-2017).

26 Yuliasri Perdani, 'Eka Kurniawan: Pramoedya's successor and antithesis', The Jakarta Post, 7-9-2015. http://www.thejakartapost.com/news/2015/og/o7/eka-kurniawan-pramoedya-s -successor-antithesis.html (accessed 25-4-2017); Ibad Durohman (2016b), 'Di balik mendunianya Eka Kurniawan', detikX (9-5-2016). https://x.detik.com/detail/metropop/2016o5 o9/Di-Balik-Mendunianya-Eka-Kurniawan/index.php (accessed 25-4-2017); Heru Triyono, 'Eka Kurniawan: Menjadi the next Pram adalah hal biasa', Beritagar, 24-3-2016. https:// beritagar.id/artikel/bincang/wawancara-novelis-eka-kurniawan-menjadi-the-next-pram -adalah-hal-biasa (accessed 25-4-2017).

27 Cited in Muhammad Hilmi, 'Tulisan dan sastra bersama Eka Kurniawan', Whiteboard Journal, 10-7-2015. http://www.whiteboardjournal.com/interview/24850/tulisan-dan-sast ra-bersama-eka-kurniawan/ (accessed 25-4-2017). 
I suggest that the answer lies in the complex combination of global power relations and local genre politics that I have examined in the preceding sections. For Eka Kurniawan, the 'keys' of international recognition and external acclaim have in many ways provided access to the locked doors and genre exclusions of the local literary canon. This process highlights the asymmetric relations between centres and peripheries of literary production. As Pascale Casanova (2004) has argued in The world republic of letters, cities like Paris, London, and New York remain key centres of publication, and writers from 'peripheral regions' typically need to be embraced by publishers and opinion makers in such centres if they are to achieve success (see also Spivak 1985, 2003).

It is important to note, however, that the admission of Eka into the canon of serious national literature in Indonesia has not occurred smoothly and seamlessly: some significant re-framing was required. Despite the spike in book sales and increased media coverage, 'vulgarity' is still an important concern. There has been a marked increase in profiles or interviews that seek to explain or excuse the 'vulgarity' of Eka Kurniawan's work. Heru Triyono writes in Beritagar: 'that's Eka: wild, but not cheap or trashy, although he often exploits sexuality.'28 Some reviewers, such as Ibad Durohman, writing for detikX, earnestly try to explain that it was Eka's limited literary influences early on in life that have resulted in his sometimes lurid prose:

Throughout Eka's youth, he never once encountered canonical Indonesian literature, like the novels of Y.B. Mangunwijaya, Ahmad Tohari, or Umar Kayam. He could only get access to the cheap pulp fiction that circulated in his local area. The works of Asmaraman S. Kho Ping Hoo, Fredy Siswanto, Abdullah Harahap, Bastian Tito, and Enny Arrow, which would have of course been banned at school. ${ }^{29}$

Statements like this imply that Eka Kurniawan could have potentially channelled his natural talent into higher-quality literature, if only he had been exposed to such influences while growing up. From the above, we can chart a sometimes uncomfortable attempt to reconcile 'international literary acclaim' and 'trashy pornographic influences' in Eka's work.

28 Heru Triyono, 'Eka Kurniawan: Menjadi the next Pram adalah hal biasa', Beritagar, 24-32016. https://beritagar.id/artikel/bincang/wawancara-novelis-eka-kurniawan-menjadi-th e-next-pram-adalah-hal-biasa (accessed 25-4-2017).

29 Ibad Durohman, 'Antara pengaruh Pram \& Enny Arrow', detikX, 9-5-2016. https://x.detik .com/detail/metropop/20160505/Kebengalan-Kebengalan-Eka-Kurniawan/index.php (accessed 25-4-2017). 
This is also evident when examining the development of the novels' cover art over the past decade. As I noted previously, the early versions of Cantik itu luka and Lelaki harimau feature overt visual markers of pulp fiction: blood, lurid colours, femme fatale women. The cover for a 2012 edition of Cantik itu luka is dominated by a semi-naked woman lying back on a bed, clutching a crimson silk sheet that matches her blood-red nails. However, following the 2015 release of the translated Beauty is a wound and Man tiger and their acclaim in the global literary press, the Indonesian language versions were re-released, this time displaying a more subdued colour palate and images more befitting of 'historical fiction' and 'family saga'. One of the updated cover images for Cantik itu luka features a demure woman in old-fashioned clothing seated beside a writing desk, against a soft brown background; another version features a cityscape of the fictional Halimunda. For the new versions of Lelaki harimau, the cover displays a stylized tiger head-quirky, cartoonish and stencil-like. I suggest that these images serve as an important site of visual translation. Cover images are paratexts that-along with reviews, interviews, and media representationsframe and position a work of fiction in a certain way. The shifting cover art of Eka Kurniawan's Indonesian-language novels reflect an increasing embrace of the global framing of his work and a move away from the original visual signifiers of the horror genre.

Yet, despite the various extra-textual translations playing out in the local and global stories circulating around Eka Kurniawan's novels, there continue to be some divergent concerns and obvious blind spots when comparing the two versions of his work. As I have described in preceding sections, descriptions of the English-language translations tend to focus on 'traditional myth' influences, while coverage of the Indonesian-language novels continue to show concern with the 'trashy pornography' influences. In addition, English-language reviews are struck by the predominance of violence in Eka Kurniawan's sweeping histories, and pass over graphic sex scenes, while Indonesian-language reviews are struck by the sex scenes but not by the graphic violence. Eka points out that before the novel was published in English, 'there was almost no discussion' about the violence and rape in Cantik itu luka:

I did a lot of research while I was writing my novel. I investigated and re-analysed Indonesian history-from what happened in the late colonial period, during the revolution of independence, at the communist massacres in 1965, through the peak of Suharto's power. It is inevitable to uncover everything; the sequence of events reveals so much violence. I am presenting it in the novel. Indonesian readers might not be surprised by it, since they knew it happened. But I also understand that when the 
book is published in English, many will think there is so much violence in my novels. And I can say, yes, indeed, there is. ${ }^{30}$

One possible reading of this statement is that the banal familiarity of violence in Indonesian history makes it unremarkable, while, in contrast, the shock value of this unknown violence for a global audience is perhaps one reason why Eka Kurniawan's work made such an impact outside Indonesia.

Moreover, this points to the underlying different perspectives that we need to take into account when following the journey of translated literature across different national contexts. As a translated work of fiction circulates globally, it does not simply encounter substantive language differences, but also highly varied interpretive contexts and standpoints. The translation of Beauty is a wound (Bi wa kizu) in Japan, for instance, has triggered some concern there around the sensitive issue of 'comfort women'. ${ }^{31}$ Yet, when read outside that context, the small handful of Japanese soldier characters are supremely unremarkable among the hundreds of men who commit sexual violence throughout the novel. Translation scholars such as Vanamala Viswanatha and Sherry Simon (2012) see the act of translation as revealing less about language and more about socio-cultural dynamics, and my analysis of the divergent readings of Eka Kurniawan's work across different times and places has supported this perspective, demonstrating that interpretive contexts and external power structures can be just as important as the content of the text.

Eka Kurniawan's somewhat delayed rise to literary fame raises important questions around what kinds of themes and genres, and even languages, are valued in different literary contexts, and how the stories circulating about a certain work of literature can be just as important as its content. In order to address these questions, this article has analysed both English- and Indonesian-language media coverage and reviews of Eka Kurniawan and his work over several years, as well as the work of visual translation that occurs through cover art choices and marketing strategies. I have paid particularly close attention to shifts and changes in these framing mechanisms as the translated works cir-

30 Cited in Nandini Nair, 'Eka Kurniawan: A terrible beauty is born', Open Magazine, 22-42016. http://www.openthemagazine.com/article/voices/eka-kurniawan-a-terrible-beauty -is-born (accessed 16-4-2017).

31 Personal communication with Ribeka Ota, 16-10-2018. 
culated globally; I have also highlighted the importance of taking into account different interpretive contexts.

In the context of Indonesia, for instance, there is a specific politics of taste and genre at play. Once a work of fiction moves out of this particular context, it is not only language that gets translated, but the meanings and connotations of certain genres as a whole. When Eka Kurniawan's work was first read in Indonesian, the genre markers of horror, pornography, and pulp fiction functioned as a barrier to his inclusion in the national literary canon. Meanwhile, the subsequent English translations of his work have been burdened with the somewhat exoticizing labels of 'local mythology' and 'magical realism'. In addition, while genre fluidity and ambiguity proved to be a huge barrier in Eka Kurniawan's initial attempts to be published in Indonesia, it is these same qualities of genre experimentation that earned him vast amounts of praise in the English-speaking literary scene.

Considering the themes of this special issue, with its focus on othering processes, both within and beyond the borders of Indonesia, the case of Eka Kurniawan offers a unique insight into how these processes affect patterns of inclusion and exclusion from both 'local' and 'global' literary canons. The initial 'othering' of horror and crime genres in the local literary scene, coupled with the productive 'othering' of the English translations, has resulted in Eka Kurniawan's novels becoming both lost and found in translation.

This case has also highlighted the asymmetric power relations of global publishing, and the ways in which external recognition from centres of literary power and taste-making can ultimately determine the fate of authors writing in more peripheral regions. Moreover, the global politics of publishing intersect here with the power structures of area studies academia, when we consider the role of Benedict Anderson in championing Eka Kurniawan's work outside Indonesia. In the contemporary scholarly context, area studies as an academic discipline has been facing an ongoing crisis of legitimacy, due to haunting legacies of Cold War approaches to understanding Asia (Harootunian 2012; Heryanto 2013; Sears and Bonura 2007). However, the example of Eka Kurniawan and Benedict Anderson reveals that, despite shrinking programmes across universities worldwide, and ongoing debates around how old models of Asian Studies are discredited and in crisis, their structures of power remain intact and have concrete impacts. Anderson, as a figure of 'area studies royalty', was easily able to provide Eka Kurniawan with access to the channels needed to make an impact in global literary circles. This points to a potential space for future research and reflection on the way our own work, as scholars of Indonesia, functions as part of the various sets of stories and paratexts circulating about particular authors and works of literature. 


\section{References}

Anderson, Benedict (2016). 'Introduction to Man tiger: A novel by Eka Kurniawan', Inside Indonesia 123 (Jan-Mar 2016), available at https://www.insideindonesia.org/ introduction-to-man-tiger-a-novel-by-eka-kurniawan.

Anwar, Wan (2007). Kuntowijoyo: Karya dan dunianya. Jakarta: Grasindo.

Bandel, Katrin (2006). Sastra, perempuan, seks. Yogyakarta: Jalasutra.

Bassnett, Susan (2013). Translation studies. New York: Routledge.

Casanova, Pascale (2004). The world republic of letters. Cambridge: Harvard University Press.

Cooper, Nancy (2004). 'Tohari's trilogy: Passages of power and time in Java', Journal of Southeast Asian Studies 35-3:531-56.

Damrosch, David (2017). How to read world literature. New Jersey: John Wiley \& Sons.

Dingwaney, Anuradha and Carol Maier (eds) (1996). Between languages and cultures: Translation and cross-cultural texts. Pittsburgh and London: University of Pittsburgh Press.

Downes, Meghan (2015). 'Critical pleasures: Reflections on the Indonesian horror genre and its anti-fans', Plaridel 12-2:1-18.

Fiske, John (1989). The John Fiske collection: Understanding popular culture. London: Routledge.

Genette, Gérard (1997). Paratexts: Thresholds of interpretation. Cambridge: Cambridge University Press.

Harootunian, Harry (2012). ' "Memories of underdevelopment” after area studies', Positions 20-1:8-35.

Heryanto, Ariel (2013). 'The intimacies of cultural and area studies: The case of Southeast Asia', International Journal of Cultural Studies 16-3:303-16.

Kurniawan, Eka (2002). Cantik itu luka. Yogyakarta: AKY.

Kurniawan, Eka (2004). Lelaki harimau. Jakarta: Gramedia Pustaka Utama.

Kurniawan, Eka (2006). Bi wa kizu, translated by R. Ota. Tokyo: Shinpusha.

Kurniawan, Eka (2008). 'Graffiti in the toilet'. Introduced and translated by Benedict Anderson. Indonesia 86 (October):55-61.

Kurniawan, Eka (2015a). Beauty is a wound, translated by A. Tucker. New York: New Directions.

Kurniawan, Eka (2015b). Man tiger, translated by L. Sembiring. New York: Verso Books.

Lefevere, Andre (1992). Translation, rewriting and the manipulation of literary fame. London and New York: Routledge.

Lefevere, Andre (2012). 'Composing the other', in: Susan Bassnett and Harish Trivedi (eds), Postcolonial translation: Theory and practice, pp. 75-94. London and New York: Routledge. 
Rahmanto, Bernardus (2001). Y.B. Mangunwijaya: Karya dan dunianya. Jakarta: Grasindo.

Ramakrishnan, J.R. (2016). 'Eka Kurniawan on Indonesia and magical realism', Electronic Literature (29January). https://electricliterature.com/eka-kurniawan-on-indo nesia-and-magical-realism-77cfbe2d2917 (accessed 16 April 2017).

Sears, Laurie and Carlo Bonura (eds) (2007). Knowing Southeast Asian subjects. Singapore: NUs Press.

Sengupta, Mahasweta (1996). 'Translation as manipulation: The power of images and images of power', in: Anuradha Dingwaney and Carol Maier (eds), Between languages and cultures. Translation and cross-cultural texts, pp.159-18o. Pittsburgh and London: University of Pittsburgh Press.

Smith-Hefner, Nancy J. (2009). "'Hypersexed” youth and the new Muslim sexology in Java, Indonesia', RIMA: Review of Indonesian and Malaysian Affairs, 43-1:209-44.

Spivak, Gayatri Chakravorty (1985). 'Three women's texts and a critique of imperialism', Critical Inquiry 12-1:243-61.

Spivak, Gayatri Chakravorty (2003). Death of a discipline. New York: Columbia University Press.

Viswanatha, Vanamala and Sherry Simon (2012). "Shifting grounds of exchange": B.M. Srikantaiah and Kannada Translation', in: Susan Bassnett and Harish Trivedi (eds), Postcolonial translation: Theory and practice. London and New York: Routledge.

Wilson, Eric (2016a). 'Review: Man Tiger strikes!', Inside Indonesia 123 (Jan-Mar), available at https://www.insideindonesia.org/review-man-tiger-strikes.

Wilson, Eric (2016b). "YYou'll learn, tough guy": On the relevance of American crime fiction and the femme fatale to Indonesian literature', Indonesian Feminist Journal $4^{-1: 63-78 . ~}$ 